\title{
Effects of Sodium Lactate, Potassium Sorbate and Cetylpyridinium Chloride on Physicochemical Properties and Microbial Count of Cold Ground Beef Meat
}

\author{
Amera M. S. Al-Rubeii \\ Animal Resources Dept., Fac. of Agric., Baghdad Univ., Abu-Ghraib , Baghdad - Iraq
}

\begin{abstract}
The objective of the present study was to investigate the effects of: $3 \%$ sodium lactate (SL), $0.2 \%$ potassium sorbate $(\mathrm{KS})$ and $0.5 \%$ cetylpyridinium chloride $(\mathrm{CPC})$ on the physicochemical properties , microbial count and sensory evaluation of ground beef, stored at $4^{\circ} \mathrm{C}$ for $\mathrm{O}, 3,6$ and 9 days.

All treatments showed significant increase in dry matter content (protein, fat and ash $)(\mathrm{P}<0.05)$ and decrease in moisture content with elongation storage time. The SL, KS and CPC significantly increased the $\mathrm{pH}$ and water holding capacity (WHC) during all the storage periods. Total volatile nitrogen (TVN), thiobarbituric acid value (TBA), peroxide value $(\mathrm{PV})$ and free fatty acids (FFA) were lower $(\mathrm{P}<0.05)$ in SL, KS and $\mathrm{CPC}$ treated samples, as compared with the control sample at any refrigerated storage period. The SL, KS and CPC caused significant $(\mathrm{P}<0.05)$ decrease in drip loss and cooking loss. Results indicated significant sensory evaluation improvement $(\mathrm{P}<0.05)$ in the organoleptic characteristics of ground beef (flavour, juiciness, tenderness, colour and overall palatability). The SL, KS and CPC significantly reduced $(\mathrm{P}<0.05)$ the total plate count and psychrophilic count during refrigerated storage periods. It can be concluded that SL, KS and CPC had positive significant influence on quality characteristics, sensing and microbial safety of ground beef when stored under refrigeration at $4 \mathrm{C}^{\circ}$ up to 9 days.
\end{abstract}

Keywords : sodium lactate, potassium sorbate, cetylpyridinium chloridesansan, ground beef.

\section{INTRODUCTION}

Although much research had been directed toward the use of organic acids to control microbial growth on carcasses, retail cuts and ground beef (Woolthuis \& Smulders, 1985, Kotula \& Thelappurate, 1994, Dorsa et al., 1997, Stivarius et al., 2002), data are limited on the use of organic acid salts, such as sodium lactate and potassium sorbate. Sodium lactate is used as humectant or flavour enhancer in cooked meat and poultry products (Federal Register, 1990). Microbial growth is inhibited by incorporation of up to $2 \%$ sodium lactate in fresh pork sausage thus, increasing the storage stability and reducing off-odour (Kuo et al., 1994). Moreover, Papadopoulas et al. (1991) reported that cooked beef containing 3-4\% sodium lactate had 2 log units reduction in microbial population during storage. The USDA (1999), issued final rule that increased the permissible levels of sodium lactate to $4-4.8 \%$ completely inhibited growth of $L$. monocylogenes and botulinum in meat and poultry (Buncic et al., 1995, Kathleen et al.,1999).

Potassium sorbate is widely used as food preservative. It is non-toxic even in large quantities.
It breaks down and it is effective against yeasts, molds and some select bacteria (CFNP 2002). Microbiological safety of some food products was best ensured by addition of potassium sorbate (Shahidi et al., 1988). Cetylpyrid-inium chloride is a quaternary ammonium compound. Its antimicrobial activity is due to an interaction of basic cetylpyridinium ions with acid groups of bacteria, which subsequently inhibits bacterial metabolism by forming weak ionic compounds that interfere with bacterial respiration (Kim \& Slavik, 1996), the permissible levels of cetylpyridinium chloride $0.5 \%$ according to Pohlman et al. (2002). While, the antimicrobial properties of reagents are well documented, no studies are available in the literature as to their effect on physicochemical properties, sensory evaluation and lipid oxidation.

Therefore, the objective of the present study was to evaluate the physicochemical properties, microbial stability and sensory properties of ground beef treated with sodium lactate, potassium sorbate and cetylpyridinium chloride during refrigeration storage at $4 \mathrm{C}^{\circ}$. 


\section{MATERIALS AND METHODS}

External fat and heavy connective tissue were trimmed off from top round of beef. Muscles were removed and formulated with addition of fat to target final level of $15 \%$ (on wet weight basis). Meat was ground twice through $0.8 \mathrm{~cm}$ plate using electric grinder (National). The minced beef was then divided into four batches $500 \mathrm{~g}$ each. Each batch was mixed by hand for $5 \mathrm{~min}$ in a plastic bag with $30 \mathrm{ml}$ (or $6 \%$ ) of each of the treatment solutions: (1) distilled water as control (C), (2) 3\% sodium lactate (SL) $(60 \%(\mathrm{w} / \mathrm{w})$ solid content $\mathrm{pH} 5.3),(3)$ $0.2 \%$ potassium sorbate $(\mathrm{KS})$ and $(4) 0.5 \%(\mathrm{w} / \mathrm{v})$ cetylpyridinium chloride (CPC), SL, KS and CPC treatments were used according to Lin \& Lin (2002) and Pohlman et al. (2002). All treatments were prepared using deionized water. Multiple trays of minced beef from each treatment were packed pending for microbial, physicochemical analysis and sensory evaluation and stored in a refrigerator $\left(4 \mathrm{C}^{\circ}\right)$ for $0,3,6$ and 9 days.

\section{Microbial sampling}

On days $0,3,6$ and 9, twenty five grams of ground beef were aseptically removed from each package, mixed with $225 \mathrm{ml}$ sterilized $0.1 \%$ peptone solution and blended for $30 \mathrm{sec}$. with stomacher. Total plate counts and psychrotrophic counts were determined following the method used by Lin \& Lin (2002).All microbial counts were reported as colony formimg units (CFU/g meat sample).

\section{Physicochemical analysis}

Samples were taken for proximate analysis including moisture, protein, fat and ash contents (AOAC, 1980). The $\mathrm{pH}$ of samples was measured (Xiong et al., 1993), together with water holding capacity "WHC" (Den Hertog-Meischke et al., 1997). Total volatile nitrogen (TVN), peroxide value (PV), free fatty acids (FFA) and thiobarbituric acid (TBA) value were also determined (Pearson et al., 1981). Myoglobin concentration was measured according to Zessin et al. (1961). Drip loss and cooking loss were determined according to Honike (1998), and Purchas \& Barton (1976), respectively.

\section{Sensory evaluation}

A trained sensory panel of eight members was requested to evaluate: flavour, juiciness, tenderness, colour and overal palataibility of cooked ground beef samples (Al-Rawi, 2005). A judging scale was as follows on a 8 point scale: 8 = extremely desirable, extremely juicy, extremely tender, dark brown, extremely desirable and $1=$ extremely undesirable, extremely dry, extremely tough, very dark red and extremely undesirable.

\section{Statistical analysis}

A $4 \times 4$ factorial design including two factors, (treatment and storage time), with three replications was analyzed by the analysis of variance (SAS, 2001). Significance between means was tested by Duncan's Multiple Range Test.

\section{RESULTS AND DISCUSSION}

Table (1) indicates the changes in proximate composition among treatments during refrigerated storage. All treatments showed significant $(\mathrm{P}<0.05)$ increase in dry matter (protein, fat and ash contents) and decrease in moisture content with storage extending period ( $0,3,6$ and 9 days). The CPC treatment had the least $(\mathrm{P}<0.05)$ dry matter and the highest moisture content at any storage period, as compared with other treatments (Table 1). The results confirm those of Lin \& Lin (2002) and Pohlman et al. (2002) on low fat Chinese- style sausages, and on ground beef, respectively, probably due to the decrease of the moisture content which was associated with storage proceeding (Xiong et al., 1993, Ageena, 2001).

The effect of salt treatments and storage period on $\mathrm{pH}$ pattern were significant $(\mathrm{P}<0.05)$ (Table 2). The CPC treatment was the highest in $\mathrm{pH}(\mathrm{P}<0.05)$ at any storage period, which was attributed to its increase in the total negative charges leading to raise the $\mathrm{pH}$ of meat (Kim \& Slavik, 1996), consequently increasing the ionic strength (IS) and increasing moisture binding. The SL treatment tended to remain the $\mathrm{pH}$ stable throughout the storage preiod that was possibly due to its buffering capacity (Papadopolous et al., 1991, Banks et al., 1998). All treatments showed a decreasing $\mathrm{pH}$ pattern (Table 2) with extending storage period. Similar results were reported by Brewer et al., 1991, Wang, 2000, Lin \& Lin, 2002 on fresh pork sausages, low fat Chinese-style sausages, and other sausages.

Table (3) presents comparisons of water holding capacity (WHC) values for treatments under investigation. Salts treatments affected WHC values positively. The CPC treatment had significantly $(\mathrm{P}<0.05)$ higher $\mathrm{WHC}$ than the other treatments at 
Table 1: Effect of SL, KS and CPC on proximate composition of ground beef during cold storage (on dry weight basis)

\begin{tabular}{|c|c|c|c|c|c|}
\hline \multirow{2}{*}{ Treatment* } & \multirow{2}{*}{ Traits } & \multicolumn{4}{|c|}{ Storage time (days) } \\
\hline & & $\mathbf{0}$ & 3 & 6 & 9 \\
\hline \multirow[t]{4}{*}{$\mathrm{C}$} & Dry Matter & $39.77 \pm 0.23^{\mathrm{Ad}}$ & $42.25 \pm 0.18^{\mathrm{Ac}}$ & $45.42 \pm 0.20^{\mathrm{Ab}}$ & $47.84 \pm 0.13 \mathrm{Aa}$ \\
\hline & Protein & $50.35 \pm 0.19 \mathrm{Cb}$ & $49.96 \pm 0.15^{\mathrm{Bb}}$ & $51.56 \pm 0.22 \mathrm{Aa}$ & $52.04 \pm 0.25^{\mathrm{Aa}}$ \\
\hline & Fat & $44.72 \pm 0.25^{\mathrm{Aa}}$ & $44.97 \pm 0.30^{\mathrm{Aa}}$ & $43.70 \pm 0.20^{\mathrm{Ab}}$ & $44.20 \pm 0.10^{\mathrm{Aab}}$ \\
\hline & Ash & $2.89 \pm 0.10^{\mathrm{Ba}}$ & $3.38 \pm 0.12^{\mathrm{Aa}}$ & $3.30 \pm 0.12^{\mathrm{Aa}}$ & $3.21 \pm 0.10^{\mathrm{Aa}}$ \\
\hline \multirow[t]{4}{*}{ SL } & Dry Matter & $34.33 \pm 0.15^{\mathrm{Ba}}$ & $41.10 \pm 0.12^{\mathrm{Bc}}$ & $43.20 \pm 0.22^{\mathrm{Bb}}$ & $44.81 \pm 0.30^{\mathrm{Ba}}$ \\
\hline & Protein & $53.45 \pm 0.18^{\mathrm{Ba}}$ & $50.97 \pm 0.20 \mathrm{Ab}$ & $51.13 \pm 0.20 \mathrm{Ab}$ & $51.57 \pm 0.22^{\mathrm{Bb}}$ \\
\hline & Fat & $41.50 \pm 0.15^{\mathrm{Bb}}$ & $43.97 \pm 0.10^{\mathrm{Ba}}$ & $43.75 \pm 0.10^{\mathrm{Aa}}$ & $43.89 \pm 0.20^{\mathrm{Aa}}$ \\
\hline & Ash & $2.91 \pm 0.05^{\mathrm{Ba}}$ & $3.40 \pm 0.01 \mathrm{Aa}$ & $3.40 \pm 0.01 \mathrm{Aa}$ & $3.34 \pm 0.01 \mathrm{Aa}$ \\
\hline \multirow[t]{4}{*}{$\mathrm{KS}$} & Dry Matter & $32.89 \pm 0.00 \mathrm{Cd}$ & $39.80 \pm 0.00 \mathrm{Cc}$ & $42.37 \pm 0.00 \mathrm{Cb}$ & $43.10 \pm 0.00 \mathrm{Ca}$ \\
\hline & Protein & $53.20 \pm 0.22^{\mathrm{Ba}}$ & $50.95 \pm 0.20^{\mathrm{Ab}}$ & $51.33 \pm 0.33 \mathrm{Ab}$ & $51.78 \pm 0.30^{\mathrm{Bb}}$ \\
\hline & Fat & $41.31 \pm 0.15^{\mathrm{Bb}}$ & $44.02 \pm 0.12^{\mathrm{Ba}}$ & $43.40 \pm 0.15^{\mathrm{Ab}}$ & $42.83 \pm 0.10^{\mathrm{Be}}$ \\
\hline & Ash & $3.41 \pm 0.02^{\mathrm{Aa}}$ & $2.88 \pm 0.02^{\mathrm{Ba}}$ & $3.18 \pm 0.01 \mathrm{Aa}$ & $3.24 \pm 0.02^{\mathrm{Aa}}$ \\
\hline \multirow[t]{4}{*}{$\mathrm{CPC}$} & Dry Matter & $31.58 \pm 0.23^{\mathrm{Dd}}$ & $38.45 \pm 0.20 \mathrm{De}$ & $41.61 \pm 0.18^{\mathrm{Db}}$ & $42.97 \pm 0.20 \mathrm{Ca}$ \\
\hline & Protein & $56.30 \pm 0.15^{\mathrm{Aa}}$ & $50.61 \pm 0.10^{\mathrm{Ad}}$ & $51.55 \pm 0.25 \mathrm{Ac}$ & $52.59 \pm 0.20 \mathrm{Ab}$ \\
\hline & Fat & $38.50 \pm 0.14 \mathrm{Cd}$ & $45.01 \pm 0.10^{\mathrm{Aa}}$ & $43.38 \pm 0.11 \mathrm{Ab}$ & $43.16 \pm 0.10^{\mathrm{Bc}}$ \\
\hline & Ash & $2.81 \pm 0.01^{\mathrm{Ba}}$ & $2.41 \pm 0.02^{\mathrm{Ba}}$ & $2.64 \pm 0.01 \mathrm{Ba}$ & $2.60 \pm 0.01 \mathrm{Ba}$ \\
\hline
\end{tabular}

* C (control), SL (sodium lactate), KS (potassium sorbate) and CPC (cetylpyridinium chloride).

Means \pm SE within the column for the same test item having unlike letters (A-D) are significantly different among treatments $(\mathrm{P}<0.05)$. Means $\pm \mathrm{SE}$ within the same row having unlike letters $(\mathrm{a}-\mathrm{d})$ are significantly different among storage time in treatment $(\mathrm{P}<0.05)$.

Table 2: Effect of SL, KS and CPC on $\mathrm{pH}$ of ground beef during cold storage

\begin{tabular}{ccccc}
\hline \multirow{2}{*}{ Treatment* $^{*}$} & \multicolumn{4}{c}{ Storage time (days) } \\
\cline { 2 - 5 } & \multicolumn{1}{c}{$\mathbf{0}$} & $\mathbf{3}$ & $\mathbf{6}$ & $\mathbf{9}$ \\
\hline $\mathrm{C}$ & $5.57 \pm 0.03^{\mathrm{Cb}}$ & $5.65 \pm 0.02^{\mathrm{Ca}}$ & $5.64 \pm 0.03^{\mathrm{Ba}}$ & $5.60 \pm 0.01^{\mathrm{Ba}}$ \\
$\mathrm{SL}$ & $6.25 \pm 0.02^{\mathrm{Ba}}$ & $6.15 \pm 0.01 \mathrm{Bb}$ & $6.12 \pm 0.01^{\mathrm{Ab}}$ & $6.10 \pm 0.01^{\mathrm{Ab}}$ \\
$\mathrm{KS}$ & $6.31 \pm 0.01^{\mathrm{ABa}}$ & $6.22 \pm 0.02 \mathrm{ABa}$ & $6.10 \pm 0.03^{\mathrm{Ab}}$ & $6.05 \pm 0.01^{\mathrm{Ab}}$ \\
$\mathrm{CPC}$ & $6.39 \pm 0.01^{\mathrm{Aa}}$ & $6.30 \pm 0.03 \mathrm{Aa}$ & $6.18 \pm 0.01^{\mathrm{Ab}}$ & $6.15 \pm 0.03^{\mathrm{Ab}}$ \\
\hline
\end{tabular}

* C (control), SL (sodium lactate), KS (potassium sorbate) and CPC (cetylpyridinium chloride).

Mean \pm SE within the column for the same test item having unlike letters (A-B) are significantly different among treatments $(\mathrm{P}<0.05)$. Means $\pm \mathrm{SE}$ within the same row having unlike letters $(\mathrm{a}-\mathrm{b})$ are significantly different among storage time in treatment $(\mathrm{P}<0.05)$.

Table 3: Effect of SL,KS and CPC on water holding capacity (WHC) of ground beef during cold storage

\begin{tabular}{lcccc}
\hline \multirow{2}{*}{ Treatment* } & $\mathbf{0}$ & $\mathbf{3}$ & $\mathbf{6}$ & $\mathbf{9}$ \\
\cline { 2 - 5 } & $56.20 \pm 0.20^{\mathrm{Da}}$ & $49.25 \pm 0.10^{\mathrm{Db}}$ & $46.19 \pm 0.10^{\mathrm{Dc}}$ & $45.42 \pm 0.20^{\mathrm{Dd}}$ \\
$\mathrm{C}$ & $63.23 \pm 0.10^{\mathrm{Ca}}$ & $56.32 \pm 0.20^{\mathrm{Cb}}$ & $53.28 \pm 0.30^{\mathrm{Cc}}$ & $52.04 \pm 0.10^{\mathrm{Bd}}$ \\
$\mathrm{SL}$ & $66.70 \pm 0.20^{\mathrm{Ba}}$ & $61.60 \pm 0.25^{\mathrm{Bb}}$ & $56.790 .10^{\mathrm{Bc}}$ & $50.05 \pm 0.20^{\mathrm{Cd}}$ \\
$\mathrm{KS}$ & $70.10 \pm 0.25^{\mathrm{Aa}}$ & $66.12 \pm 0.10^{\mathrm{Ab}}$ & $62.30 \pm 0.20^{\mathrm{Ac}}$ & $56.65 \pm 0.20^{\mathrm{Ad}}$ \\
$\mathrm{CPC}$ &
\end{tabular}

* C (control), SL (sodium lactate), KS (potassium sorbate) and CPC (cetylpyridinium chloride).

Means \pm SE within the column for the same test item having unlike letters (A-B) are significantly different among treatments $(\mathrm{P}<0.05)$. Means \pm SE within the same row having unlike letters $(\mathrm{a}-\mathrm{b})$ are significantly different among storage time in treatment $(\mathrm{P}<0.05)$. 
any storage time. On the other hand, $\mathrm{C}$ treatment exhibited lower WHC than others at any storage period. Addition of CPC (its mean ions $\mathrm{Cl}^{-}$) not only raised the $\mathrm{pH}$ of meat but also increased the total negative charges on myofibrillar proteins (Kerry et al., 2002). Both actions accounted for increased WHC. All treatments showed a gradual decrease in WHC (Table 3) as storage time was extended. Such results agree with the findings of Lin \& Lin (2002) who showed a decrease in the values of WHC in salt treatments in low fat Chinese- style sausages was associated with extending storage period.

The total volatile nitrogen (TVN) could be used as a quality indicator for meat (Ageena, 2001), and in association with the amino acid decarboxylase activity of microorganisms during storage. Changes in TVN value during storage are shown in Table (4). The SL had significant $(\mathrm{P}<0.05)$ lower TVN value than other treatments, while $\mathrm{C}$ treatment remained at higher $(\mathrm{P}<0.05)$ TVN suggesting greater bacterial population and activity, which confirmed Lin $\&$ Lin (2002) findings on TVN for low-fat Chinesestyle sausage with addition of 3\% SL than for the control. All treatments showed significant $(\mathrm{P}<0.05)$ increases in TVN value with increasing refrigerated storage (Table 4). The present data support those reported by Celik (1995) who found that the TVN value in raw beef meat of $9.39 \mathrm{mg} \mathrm{N} / 100 \mathrm{~g}$ meat to increase to $75.44 \mathrm{mg} \mathrm{N} / 100$ meat after 15 days of storage under refrigeration. Thus, TVN in meat increased with increasing storage time possibly due to changes and proteolysis in myofibrillar protein during storage, also might be due to increased action of proteolytic enzyme that contribute to increased accumulation of free nitrogen groups that might lead to higher TVN value (Ageena, 2001).

Table (5) gives changes in myoglobin concentration during refrigerated storage of ground beef among the studied treatments. All treatments showed significant $(\mathrm{P}<0.05)$ increase in myoglobin concentration as storage time proceeded, due to oxidation of myoglobin pigment to metmyoglobin during storage (Chen et al., 1992, Banks et al., 1998). The CPC treatment was the highest $(\mathrm{P}<0.05)$ at any storage time, while $\mathrm{C}$ treatment had the least values $(\mathrm{P}<0.05)$ at any storage time, the magnitudes of differences among salt treatments were small. Such results agree with those of Al-Rawi (2005) on minced and frozen beef.

The effect of salt treatments on thiobarbituric acid (TBA) values is summarized in Table (6). The
TBA values among treatments followed a similar increasing $(\mathrm{P}<0.05)$ trends with refrigerated storage period ,but the values in all treatments were less $(\mathrm{P}<0.05)$ than that in $\mathrm{C}$ treatment .Similar findings were observed by Brewer et al. (1992) and Celik (1995) who showed that TBA values in raw fresh beef of $0.22 \mathrm{mg}$ malonaldehyde $/ \mathrm{kg}$ meat increased to $0.91 \mathrm{mg}$ malonaldehyde $/ \mathrm{kg}$ meat after 15 days refrigeration, and that was probably due to lipid oxidation resulting from action of lipase or phospholipase (Raharjo et al., 1992). The COSQC (1987) issued a final rule that if the TBA value increased to more than $2.0 \mathrm{mg}$ malonaldehyde $/ \mathrm{kg}$ of meat the meat is inadmissible or refused.

Peroxide values (PV) for the treatments under study are shown in Table (6). All salt treatments had the least significant $(\mathrm{P}<0.05) \mathrm{PV}$ at any storage period. On the other hand, the $\mathrm{C}$ treatment recorded the highest significant $(\mathrm{P}<0.05) \mathrm{PV}$ at any storage period. Generally, all treatments showed significant increase in PV with increasing refrigerated storage, and which had thought to be due to action of lipolysis enzymes such as, lipase and phospholipase on lipids in meat particularly their phospholipids components undergoing degradation to produce a large number of compounds such as, hydroperoxides, aldehydes and ketones being are responsible for the development of undesirable aroma and deterioration in flavour (rancidity) during storage (Kerry et al., 2002). Similar results were reported by Smith et al. (1985) and Berry (1991) on frozen ground beef patties. The COSQC (1987) issued a final rule that the increase of the PV more than 10 milli equivalents peroxide $/ \mathrm{Kg}$ of meat resulted in that the meat is inadmissible or refused.

Free fatty acid (FFA) values for salt treated ground beef during refrigerated storage are listed in Table (6). Nonsignifcant differences in FFA among the treatments were found at any storage period. In general, FFA values among treatments followed similar increasing trends with storage period ,but $\mathrm{C}$ treatment was the highest significant $(\mathrm{P}<0.05)$ at any storage period, possibly due to the action of lipolytic enzymes (lipase and phosphplipase) on lipid leading to increase the release of free fatty acids which contribute positively to the generation of undesirable aromas as well as flavour. On the other hand, the salt treatments recorded the lowest significant $(\mathrm{P}<0.05) \mathrm{FFA}$ at any storage period, which may lead to the desirable aroma and flavour. Similar results were reported by Kim et al. (1988) and Muller 
Table 4: Effect of salt treatment (SL, KS and CPC)on total volatile nitrogen (TVN) (mgN/100) of ground beef during cold storage

\begin{tabular}{lcccc}
\hline \multirow{2}{*}{ Treatment* $^{*}$} & \multicolumn{4}{c}{ Storage time (days) } \\
\cline { 2 - 5 } & $\mathbf{0}$ & $\mathbf{3}$ & $\mathbf{6}$ & $\mathbf{9}$ \\
\hline $\mathrm{C}$ & $8.20 \pm 0.10^{\mathrm{Ad}}$ & $12.60 \pm 0.20^{\mathrm{Ac}}$ & $15.50 \pm 0.10^{\mathrm{Ab}}$ & $16.80 \pm 0.10^{\mathrm{Aa}}$ \\
$\mathrm{SL}$ & $5.10 \pm 0.30^{\mathrm{Cc}}$ & $8.10 \pm 0.10^{\mathrm{Cb}}$ & $10.80 \pm 0.25^{\mathrm{Cad}}$ & $11.30 \pm 0.10^{\mathrm{Ca}}$ \\
$\mathrm{KS}$ & $6.60 \pm 0.20^{\mathrm{Bc}}$ & $10.22 \pm 0.20^{\mathrm{Bb}}$ & $12.01 \pm 0.15^{\mathrm{Ba}}$ & $12.82 \pm 0.30^{\mathrm{Ba}}$ \\
$\mathrm{CPC}$ & $6.90 \pm 0.10^{\mathrm{Bc}}$ & $10.31 \pm 0.10^{\mathrm{Bb}}$ & $12.25 \pm 0.15^{\mathrm{Ba}}$ & $13.05 \pm 0.15^{\mathrm{Ba}}$ \\
\hline
\end{tabular}

* C (control), SL (sodium lactate), KS (potassium sorbate) and CPC (cetylpyridinium chloride).

Means \pm SE within the column for the same test item having unlike letters (A-B) are significantly different among treatments $(\mathrm{P}<0.05)$. Means $\pm \mathrm{SE}$ within the same row having unlike letters $(\mathrm{a}-\mathrm{b})$ are significantly different among storage time in treatment $(\mathrm{P}<0.05)$.

Table 5: Changes in myoglobin concentration ( $\mathrm{mg} / \mathrm{g}$ meat) of ground beef containing various salt treatments (SL, KS and CPC) during cold storage

\begin{tabular}{lcllc}
\hline \multirow{2}{*}{ Treatment* } & \multicolumn{4}{c}{ Storage time (days) } \\
\cline { 2 - 5 } & \multicolumn{1}{c}{$\mathbf{0}$} & $\mathbf{3}$ & \multicolumn{1}{c}{$\mathbf{6}$} & $\mathbf{9}$ \\
\hline $\mathrm{C}$ & $4.40 \pm 0.10^{\mathrm{Ab}}$ & $4.53 \pm 0.03^{\mathrm{Ca}}$ & $4.54 \pm 0.05^{\mathrm{Ca}}$ & $4.57 \pm 0.03^{\mathrm{Ba}}$ \\
$\mathrm{SL}$ & $4.51 \pm 0.05^{\mathrm{Ab}}$ & $4.87 \pm 0.05^{\mathrm{Bb}}$ & $4.93 \pm 0.03^{\mathrm{Aa}}$ & $5.10 \pm 0.05^{\mathrm{Aa}}$ \\
$\mathrm{KS}$ & $4.43 \pm 0.05^{\mathrm{Ab}}$ & $4.55 \pm 0.02^{\mathrm{Cab}}$ & $4.71 \pm 0.03^{\mathrm{Ba}}$ & $4.91 \pm 0.02^{\mathrm{Aa}}$ \\
$\mathrm{CPC}$ & $4.55 \pm 0.03^{\mathrm{Ab}}$ & $5.06 \pm 0.02^{\mathrm{Aa}}$ & $5.10 \pm 0.01^{\mathrm{Aa}}$ & $5.14 \pm 0.02^{\mathrm{Aa}}$ \\
\hline
\end{tabular}

* C (control), SL (sodium lactate), KS (potassium sorbate) and CPC (cetylpyridinium chloride).

Means \pm SE within the column for the same test item having unlike letters (A-B) are significantly different among treatments $(\mathrm{P}<0.05)$. Means $\pm \mathrm{SE}$ within the same row having unlike letters $(\mathrm{a}-\mathrm{b})$ are significantly different among storage time in treatment $(\mathrm{P}<0.05)$.

Table 5: Changes in myoglobin concentration ( $\mathrm{mg} / \mathrm{g}$ meat) of ground beef containing various salt treatments (SL, KS and CPC) during cold storage

\begin{tabular}{llcccc}
\hline \multirow{2}{*}{ Traits } & Treat.* & \multicolumn{4}{c}{ Storage time (days) } \\
\cline { 3 - 6 } & & $\mathbf{0}$ & $\mathbf{3}$ & $\mathbf{6}$ & $\mathbf{9}$ \\
\hline TBA & $\mathrm{C}$ & $0.35 \pm 0.05^{\mathrm{Ac}}$ & $0.51 \pm 0.06^{\mathrm{Ab}}$ & $0.64 \pm 0.06^{\mathrm{Aa}}$ & $0.70 \pm 0.05^{\mathrm{Aa}}$ \\
mg malonaldehyde/ $\mathrm{kg}$ & $\mathrm{SL}$ & $0.26 \pm 0.03^{\mathrm{Bb}}$ & $0.29 \pm 0.01^{\mathrm{Bb}}$ & $0.31 \pm 0.01^{\mathrm{Bab}}$ & $0.36 \pm 0.02^{\mathrm{Bab}}$ \\
& $\mathrm{KS}$ & $0.22 \pm 0.01^{\mathrm{Bb}}$ & $0.24 \pm 0.001^{\mathrm{Bb}}$ & $0.29 \pm 0.01^{\mathrm{Bab}}$ & $0.33 \pm 0.02^{\mathrm{Ba}}$ \\
& $\mathrm{CPC}$ & $0.25 \pm 0.01^{\mathrm{Bb}}$ & $0.31 \pm 0.01^{\mathrm{Bab}}$ & $0.35 \pm 0.001^{\mathrm{Ba}}$ & $0.38 \pm 0.002^{\mathrm{Ba}}$ \\
& $\mathrm{C}$ & $2.23 \pm 0.01^{\mathrm{Ac}}$ & $3.55 \pm 0.01^{\mathrm{Ab}}$ & $4.39 \pm 0.01^{\mathrm{Aa}}$ & $4.67 \pm 0.05^{\mathrm{Aa}}$ \\
PV & $\mathrm{SL}$ & $1.50 \pm 0.06^{\mathrm{Bb}}$ & $1.67 \pm 0.05^{\mathrm{BCb}}$ & $1.80 \pm 0.05^{\mathrm{Ba}}$ & $2.05 \pm 0.03^{\mathrm{Ba}}$ \\
& $\mathrm{KS}$ & $1.45 \pm 0.06^{\mathrm{Bc}}$ & $1.56 \pm 0.05^{\mathrm{Cbc}}$ & $1.68 \pm 0.04 \mathrm{Cb}$ & $1.98 \pm 0.03^{\mathrm{Ba}}$ \\
& $\mathrm{CPC}$ & $1.52 \pm 0.05^{\mathrm{Ba}}$ & $1.74 \pm 0.03^{\mathrm{Bb}}$ & $1.87 \pm 0.05^{\mathrm{Bb}}$ & $2.09 \pm 0.05^{\mathrm{Ba}}$ \\
& $\mathrm{C}$ & $0.31 \pm 0.05^{\mathrm{Ac}}$ & $0.64 \pm 0.06^{\mathrm{Ab}}$ & $0.83 \pm 0.05^{\mathrm{Aa}}$ & $0.92 \pm 0.01^{\mathrm{Aa}}$ \\
& $\mathrm{SL}$ & $0.20 \pm 0.01^{\mathrm{Bb}}$ & $0.30 \pm 0.01^{\mathrm{Ba}}$ & $0.30 \pm 0.01^{\mathrm{Ba}}$ & $0.37 \pm 0.02^{\mathrm{Ba}}$ \\
& $\mathrm{KS}$ & $0.18 \pm 0.05^{\mathrm{Bb}}$ & $0.25 \pm 0.01^{\mathrm{Ba}}$ & $0.27 \pm 0.01^{\mathrm{Ba}}$ & $0.31 \pm 0.01^{\mathrm{Ba}}$ \\
& $\mathrm{CPC}$ & $0.22 \pm 0.03^{\mathrm{Bb}}$ & $0.29 \pm 0.03^{\mathrm{Bb}}$ & $0.36 \pm 0.03 \mathrm{Ba}$ & $0.41 \pm 0.01^{\mathrm{Ba}}$ \\
\hline
\end{tabular}

* C (control), SL (sodium lactate), KS (potassium sorbate) and CPC (cetylpyridinium chloride).

Significantly different among treatments $(\mathrm{P}<0.05)$. Means \pm SE within the same row having unlike letters $(\mathrm{a}-\mathrm{d})$ are significantly different among storage time in treatment $(\mathrm{P}<0.05)$. 
et al. (1991), on frozen stored beef and structured beef steak. The COSQC (1987) issued a final rule that increase the FFA more than $1.5 \%$ resulted in that the meat is inadmissible or refused.

Drip loss and cooking loss percentage are present in Table (7). All salt treatments recorded significant $(\mathrm{P}<0.05)$ decrease in both drip loss and cooking loss percentages at any storage period as compared with the $\mathrm{C}$ treatment probably due to the role of salts in increasing moisture binding, water holding capacity and decreasing free water percent which led to increase ability of meat tissue to retain water and reducing moisture loss during storage and cooking (Lin \& Lin, 2002, Al-Rawi, 2005). The results obtained here supported earlier findings where salts used in meat greatly influenced moisture retention and reduction drip loss and cooking loss percentages during storage time (Louis et al., 1987, Al-Rawi, 2005).

Sensory panel evaluation values for the stored ground beef are listed in Table (8). The organoleptic scores for flavour, juicinees, tenderness, colour and overall palatability of cooked ground beef were significantly $(\mathrm{P}<0.05)$ different for all the treatment at any storage time.After storage, salt treatments were much significantly $(\mathrm{P}<0.05)$ better than that of the $\mathrm{C}$ treatment in overall organoleptic properties. This was due to increasing juiciness and tenderness of the treated meat with salts which affected flavour and caused the increasing of overall palatability of ground beef. Such results are in agreement with the findings of Al-Rawi (2005) who found significant improvement in sensory evaluation of meat treated with salts ( $\mathrm{NaCl}$, sodium tripolyphosphate) during frozen storage.

The number of total plate count (TPC) for ground beef stored under refrigeration are presented in Fig. (1). Ground beef containing SL had siginficantly $(\mathrm{P}<0.05)$ lower TPC at any storage period than the other treatments. Brewer et al. (1993) reported similar results in retarding microbial growth when 2 or 3\% SL was included in pork sausage. Bacteriostatic effect on microbial growth and shelf life extenstion to 25 days at $20^{\circ} \mathrm{C}$ were demonstrated in Chinese-style sausage with $3 \% \mathrm{SL}$ added (Wang, 2000). The $\mathrm{C}$ treatment appeared to be higher $(\mathrm{P}<0.05)$ in TPC than all treatments indicating that higher microbial populations in ground beef was associated with increasing storage time. The KS was currently used as preservation in great variety of meat in Taiwan (Lin \& Lin, 2002) and the results obtained here indicated an intermediate antibacterial action. The CPC treatment had been shown to be effective significantly $(\mathrm{P}<0.05)$ in reducing microbial populations as compared to C. Such results agree with the findings of Pohlman et al. (2002) who showed that using 0.5\% CPC during the production of ground beef significantly $(\mathrm{P}<0.05)$ inhibited microbial growth.

Results of the current study concerning the effect of salt treatments (SL, KS, CPC) on psychrotrophilic count (PTC) in ground beef are presented in Fig (2). Microbial growth followed similar trends in all salt treatments with SL being significantly $(\mathrm{P}<0.05)$ the lowest among PTC at any storage periods than other treatments. The $\mathrm{C}$ treatment appeared

Table 7: Effect of salt treatment (SL, KS and CPC) on drip loss and cooking loss of ground beef during cold storage

\begin{tabular}{clllcc}
\hline \multirow{2}{*}{ Traits } & Treat. & \multicolumn{4}{c}{ Storage time (days) } \\
\cline { 3 - 6 } & & \multicolumn{1}{c}{$\mathbf{0}$} & $\mathbf{3}$ & $\mathbf{6}$ & $\mathbf{9}$ \\
\hline Drip loss (\%) & $\mathrm{C}$ & $1.89 \pm 0.01^{\mathrm{Ad}}$ & $2.39 \pm 0.01^{\mathrm{Ac}}$ & $3.05 \pm 0.03^{\mathrm{Ab}}$ & $3.86 \pm 0.02^{\mathrm{Aa}}$ \\
& $\mathrm{SL}$ & $1.71 \pm 0.05 \mathrm{Bb}$ & $1.79 \pm 0.02^{\mathrm{Bb}}$ & $1.95 \pm 0.02^{\mathrm{Ba}}$ & $2.06 \pm 0.01^{\mathrm{Ba}}$ \\
& $\mathrm{KS}$ & $1.66 \pm 0.03^{\mathrm{Bb}}$ & $1.75 \pm 0.02^{\mathrm{Bab}}$ & $1.84 \pm 0.02^{\mathrm{Ba}}$ & $1.95 \pm 0.03^{\mathrm{Ba}}$ \\
& $\mathrm{CPC}$ & $1.56 \pm 0.02^{\mathrm{Bb}}$ & $1.67 \pm 0.03^{\mathrm{Bb}}$ & $1.72 \pm 0.01^{\mathrm{Bab}}$ & $1.81 \pm 0.02^{\mathrm{Ba}}$ \\
& $\mathrm{C}$ & $2.90 \pm 0.03^{\mathrm{Ac}}$ & $3.15 \pm 0.05^{\mathrm{Ac}}$ & $3.72 \pm 0.05^{\mathrm{Ab}}$ & $4.15 \pm 0.02^{\mathrm{Aa}}$ \\
& $\mathrm{SL}$ & $2.20 \pm 0.03^{\mathrm{Bb}}$ & $2.30 \pm 0.02^{\mathrm{Bb}}$ & $2.67 \pm 0.03^{\mathrm{Bab}}$ & $2.89 \pm 0.05^{\mathrm{Ba}}$ \\
& $\mathrm{KS}$ & $2.11 \pm 0.02^{\mathrm{Bb}}$ & $2.23 \pm 0.02^{\mathrm{Bab}}$ & $2.25 \pm 0.01 \mathrm{Ca}$ & $2.40 \pm 0.03 \mathrm{Ca}$ \\
& $\mathrm{CPC}$ & $1.90 \pm 0.01^{\mathrm{Bb}}$ & $2.10 \pm 0.03^{\mathrm{Bb}}$ & $2.39 \pm 0.03^{\mathrm{Cab}}$ & $2.52 \pm 0.02^{\mathrm{Ca}}$ \\
\hline
\end{tabular}

* C (control), SL (sodium lactate), KS (potassium sorbate) and CPC (cetylpyridinium chloride).

Means \pm SE within the column for the same test item having unlike letters (A-B) are significantly different among treatments $(\mathrm{P}<0.05)$. Means $\pm \mathrm{SE}$ within the same row having unlike letters $(\mathrm{a}-\mathrm{b})$ are significantly different among storage time in treatment $(\mathrm{P}<0.05)$. 


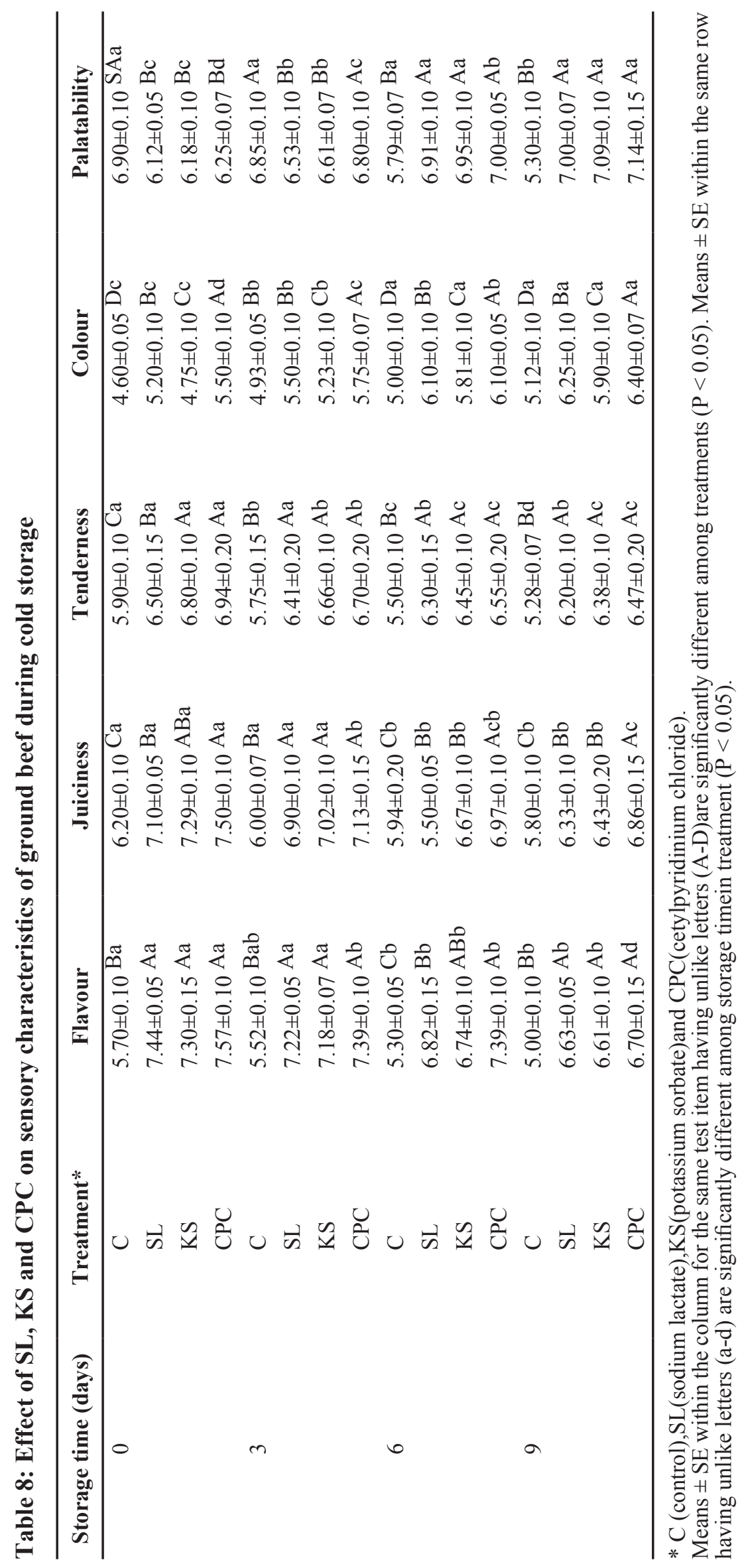




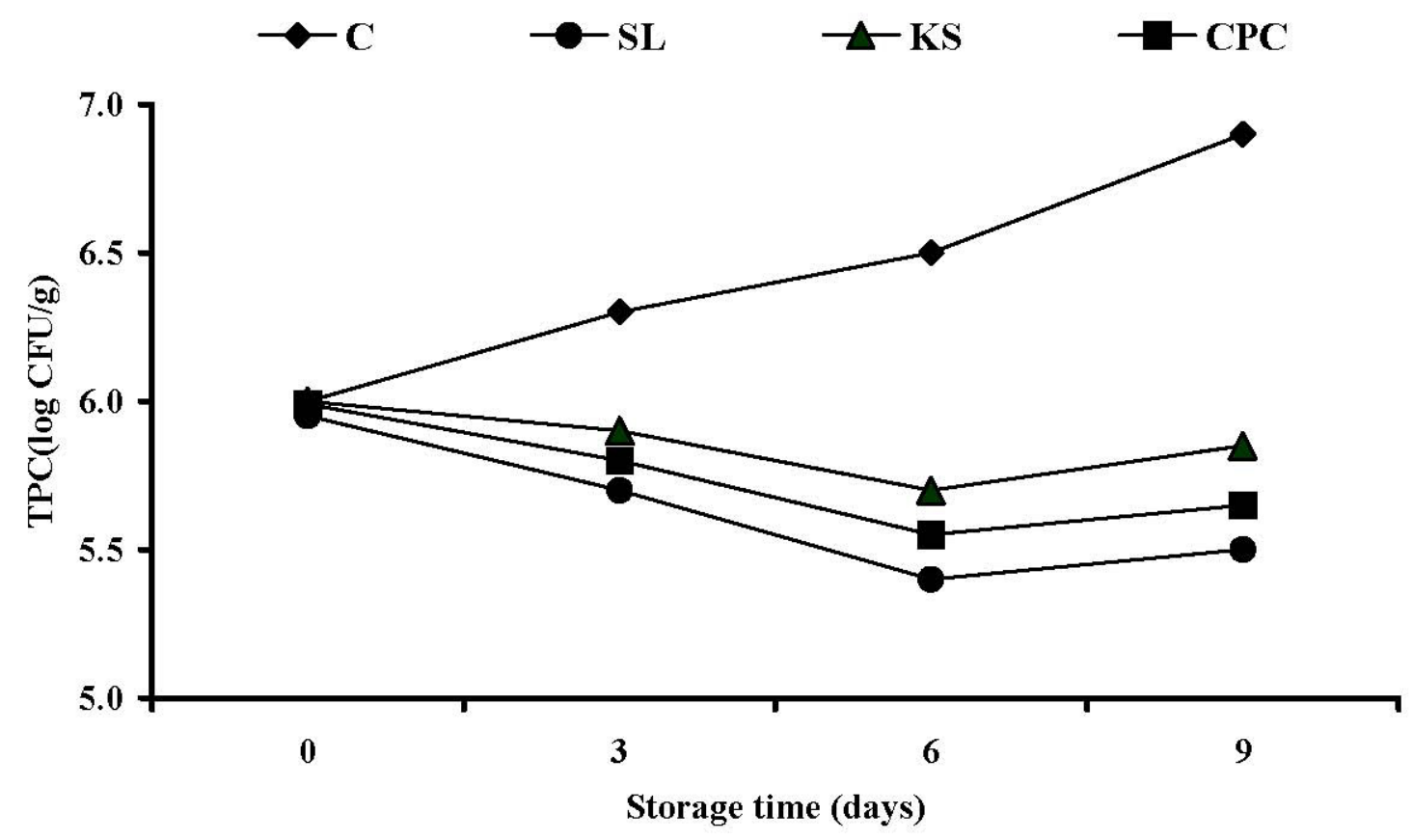

Fig. 1: Changes in total plate count (TPC) of ground beef containing salt treatment during cold storage

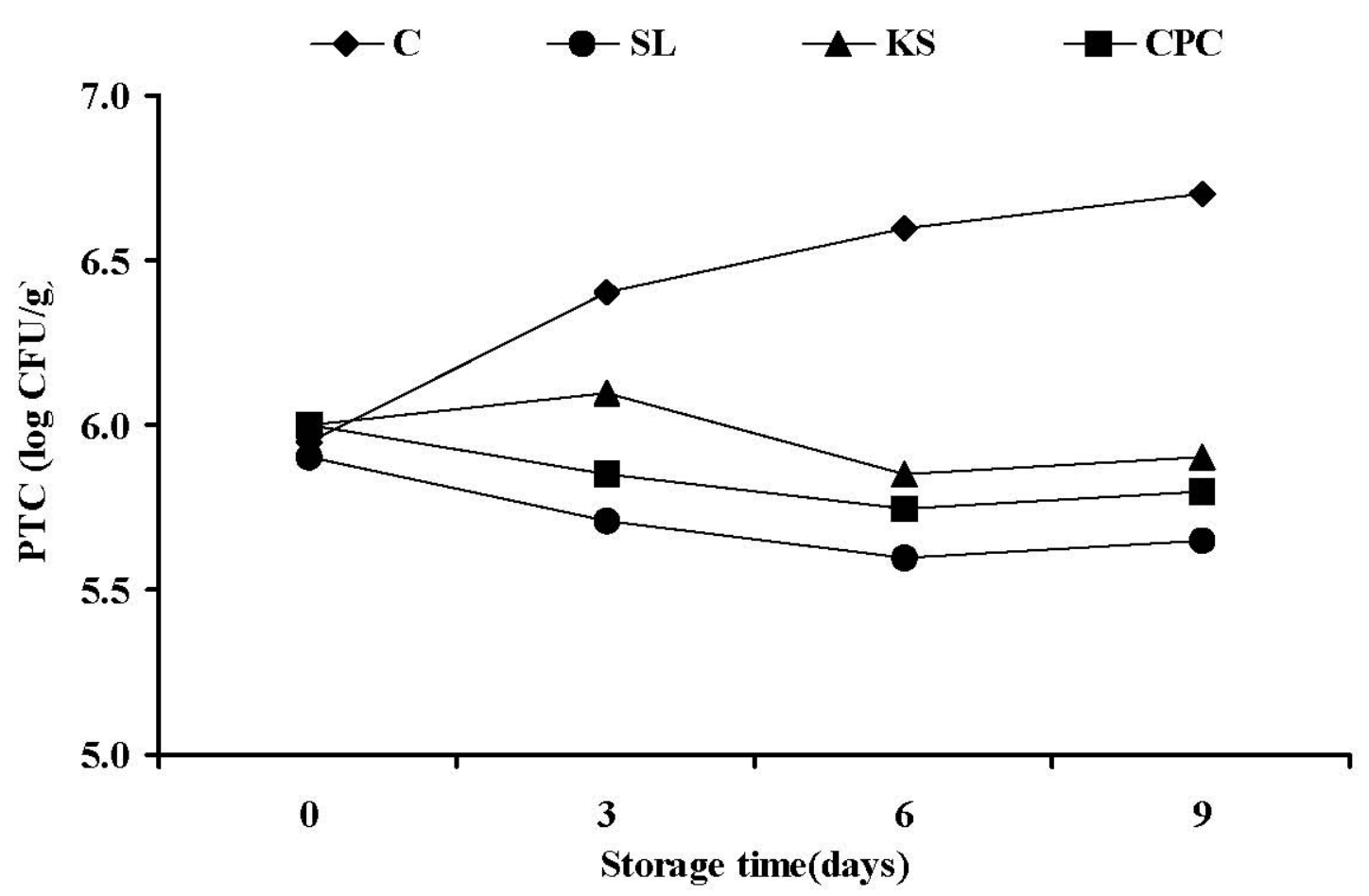

Fig. 2: Changes in psychrotrophilic count (PTC) of ground beef containing salt treatment during cold storage 
to be $(\mathrm{P}<0.05)$ higher in PTC than all other treatments. The significant differences $(\mathrm{P}<0.05)$ among salt treatments were recorded .Similar results were reported by Pohlman et al. (2002) and Lin \& Lin (2002) for low fat Chinese-style sausages.

\section{CONCLUSION}

Data of the present study suggested that salts (SL, KS and CPC) could be utilized to keep or improve the quality characteristics of cold stored ground beef for a limited period. The use of such salts which has no deleterious effects on the sensory characteristics, improved to some extend the microbial stability of ground beef during storage under refrigeration at $4 \mathrm{C}^{\circ}$ for about 9 days as demonstrated in the present work.

\section{REFERENCES}

Ageena, S.J.M. 2001. Effect of Freezing Storage Time and Packaged Factor of the Calve Meat on its Expire for Consumption with Chemical, Sensory and Bacterial Indicators. Ms. Thesis. Food Science and Biotechnology. College of Agriculture. University of Baghdad. Iraq.

Al-Rawi, M.A.N. 2005. Effect of Sodium Chloride and Sodium Tripoly Phosphate on Quality Characteristics of Minced and Frozen Beef Meat. Ms. Thesis. Food Science and Biotechnology. College of Agriculture. University of Baghdad. Iraq.

A.O.A.C. 1980. Official Methods of Analysis, 13th ed. Association of Official Analytical Chemists. Washington, DC.

Banks, W.T., C., Wang \& M.S., Brewer 1998. Sodium lactate /sodium tripolyphosphate combination effects on aerobic plate counts, $\mathrm{pH}$ and colour of fresh pork Longissimus muscle. Meat Sci., 50: 499-504.

Berry, B.W. 1991. Effects of soy protein and freezing treatments on cooking loss and compostion of beef patties. J. Musle Foods, 2: 105-118.

Brewer, M.S., F.K., Mekieth, S.E., Martin, A.W., Dallmier \& J., Meyer 1991. Sodium lactate effects on shelf-life, sensory and physical characteristics of fresh pork sausage. J. Food Sci., 56: 1176-1178.

Brewer, M.S., F.K.Mekieth and K. Britt.1992. Fat, soy and carrageenan effect on sensory and physcial characteristics of ground beef pat- ties. J. Food Sci., 57: 1051-1053.

Brewer, M. S., F.K. Mekieth \& G., Sprouls. 1993. Sodium lactate effects on microbial sensory and physical characteristics of vacuum-package pork sausage. J. Muscle Foods, 4: 179192.

Buncic, S., C.M., Fitzerald, R.G., Bell \& J.A., Hudson. 1995. Individual and combined listericidal effects of sodium lactate, potassium sorbate, nicin and curing salts at refrigeration temperature. J. Food Safety, 15: 247-264.

Celik, T. 1995. Determination of spoilage and putrefaction in raw fresh beef with organoleptic evaluations and chemical analysis, Thesis Abstracts Service, Health sciences Institute Ankara University, Ankara Turkey.

COSQC, 1987. Central Oraganization Standardization and Quality Control.. Red Meat N. 2688. Baghdad, Iraq .

Chen, C.M., D.L., Huffman, W.R., Egbert \& R.C., Smith. 1992. Oxidation of purified bovine myoglobin :Effects of $\mathrm{pH}$, sodium chloride, tripolyphosphate and binders. J. Agric. Food Chem., 40: 1767- 1771.

CFNP, 2002. Tap Review. Directly referenced from http://www.soybean.com/ps.htm.

DenHertog-Meischke, M.J.A., F.J.M., Smulderes, Vanloglestijn \& Vanknapen, F. 1997. The effect of electrical stimulation on the water holding capacity and protein denaturation of two bovine muscles . J. Anim. Sci., 75: 118-124.

Dorsa, W.J., C.N., Cutter \& G.R., Sirgusa 1997. Effects of acetic acid, lactic acid and trisodium phosphate on the microflora of refrigerated beef carcass surface tissue inoculated with Escherichia coli O157: H7, Listeria innocua and Clostridium sporogenes. J. Food Protection, 60: 619-624.

Federal Register 1990. Sodium lactate and potassium lactate as flavour enhancers and flavouring agents in various meat and poultry products. Federal Register, 55: 7339.

Honike, K.O. 1998. Reference methods for the assessment of physical characteristics of meat. Meat Sci. 49: 447-457.

Kathleen, G,S., Angelique, G., Daw. \& J. Eric. 1999. Effect of sodium lactate, sodium diacetate and monolaurin on Listeria moncytogens 
on processed meat products. Annual Report, Food Research Institute.

Kerry, J., J.D. Kerry \& D., Ledward 2002. Meat Processing Improving Ouality. Woodhead Publishing Limited. Cambridge CBI 6AH, England.

Kim, J.W. \& M.F. Slavik 1996. Cetylpyridinium chloride (CPC) treatment on poultry skin to reduce attached Salmonella. J. Food protection, 59 (3): 322-326.

Kim, Y.H., S.Y. Yang \& M.H. Lee 1988. The effects of freezing rates on the physcio-chemical changes of beef during frozen storage at-20 deg C. Koream J. Food Sci. Technol., 447-452.

Kotula, K.L. \& R. Thelappurate 1994. Microbiological and sensory attributes of retail cuts of beef treated with acetic and lactic acid solution .J.Food Protection, 57: 665-670.

Kuo, J.C., J. Dresel \& L. Leistner 1994. Effects of sodium lactate and storage temperature on growth and survival of Salmonella in Chinese sausage. Food Sci., 21: 182-196.

Lin, K.W. and S.N. Lin 2002. Effects of sodium lactate and trisodium phosphate on the physicochemical properties and shelf life of low fat Chinese-style sausage.Meat Sci., 60:147-154.

Louis, L., C.E. Young, G.K.S. Lyon \& R.L. Wilson. 1987. Influence of sodium tripolyphosphate and sodium chloride on moisture-retention and textural characteristics of chicken breast meat patties. J. Food Sci., 52: 571-574.

Mullar, T.S., R.C. Johnson, W.J. Costello, J.R. Romans \& K.W. Jones 1991. Storage of structured beef steak batties produced with algin/calicium/adipic acid gel. J. Food Sci., 56 (3):104.

Papadopoulos, L.S., R.K., Miller, G.R., Acuff, C., Vanderzant \& H.R. Cross 1991. Effect of sodium lactate on microbial and chemical composition of cooked beef during storage. J. Food Sci., 56: 341-347.

Pearson, D., H. Egan, R.S. Kirk \& R. Sawyer 1981. Chemical Analysis of Food. Longman Scientific and Technical New York

Pohlman, F.W., M.R. Stivarius, K.S. McElyeaand A.L. Wald 2002. Reduction of E.coli, Salmonella typhimurium, coliforms, aerobic bacteria, and improvement of ground beef colour using trisodium phpsphate or cetylpyridinium chloride before grinding. Meat Sci., 60: 349-356.

Purchas, R.W. \& R.A. Barton 1976. The tenderness of meat of several breeds of cattle raised under New Zealand pastoral condition. New Zealand J. Agric. Res. 19: 421-428.

Raharjo, S., J.N. Solo \& G.R. Schmidt 1992. Improved speed, specificity and limit of determination of aqueous acid extraction thiobarbituric acid- C18 method for measuring lipid peroxidation in beef. J. Agric. Food Chem., 40: $2182-2185$.

SAS. 2001. SAS User's Guid: Statistics (Version 6.0). SAS Inst. Inc. Cary. NC. USA.

Shahidi, F., L.J. Rubin \& D.F.Wood 1988. Stabilization of meat lipids with nitrite-free curing mixtures. Meat Sci., 22: 73-80.

Smith, J.J., S.C. Seideman, R.L. Rosenkrans \& J.L. Secrist 1985. Vaccum packaged trimming as a source for ground beef patties: changes during one year of frozen storage. J. Food Prot., 48: 200-206.

Stivarius, M.R., F.M. Pohlman, K.S. McElyea \& A.L. Waldroup 2002. Effects of hot water and lactic acid treatment of beef trimmings prior to grinding on microbial, instrumental colour and sensory properties of ground beef during display. Meat Sci., 60: 327-334.

USDA 1999. Food Safety and Inspection Service United States Department of Agriculture (USDA, U.S.A.).

Wang, F.S. 2000. Effects of three preservatives on the shelf life of vacuum packaged Chinesestyle sausage stored at $20 C^{\circ}$. Meat Sci., 56: $67-71$.

Woolthuis, C.H.J. \& F.J.M. Smulders 1985. Microbial decontamination of calf carcasses by lactic acid sprays . J. Food Protection, 48: 832-837.

Xiong, Y. L., A.H. Cantor, A.J. Pescatore, S.P. Blanchard \& M.L. Straw 1993. Variations in muscle chemical compositions, $\mathrm{pH}$, and protein extractability among eight different broiler crosses. Poultry Sci., 72:583-588.

Zessin, D.A., C.V. Pohu, G.D. Wilson \& D.S. Carrigan 1961. Effect of pre-slaughter dietary stress on the carcass characteristics and palatability of pork. J. Anim. Sci., 20: 871-876. 


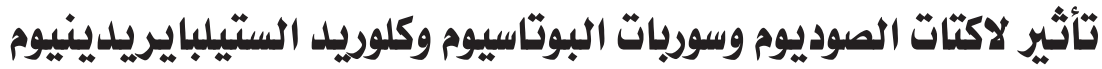

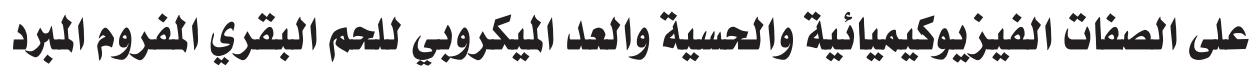

\author{
أميرة محمد صالح الربيعي \\ قسم الانتاج الحيواني- كلية الزراعة - جامعة بغداد - العراق الفئر
}

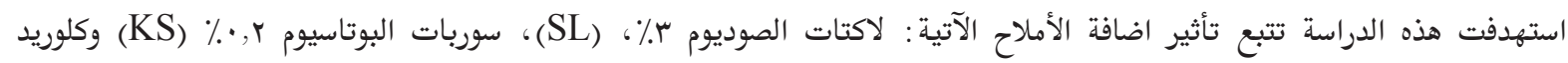

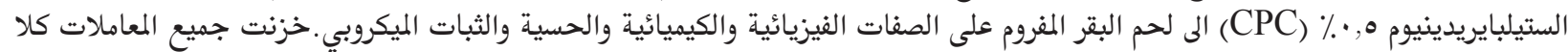

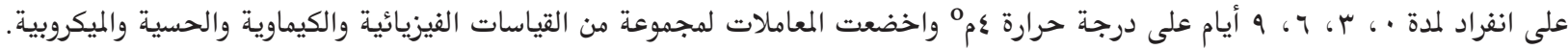

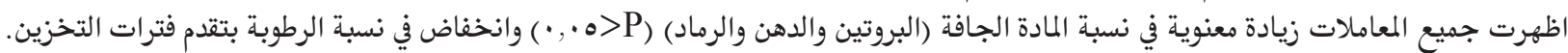

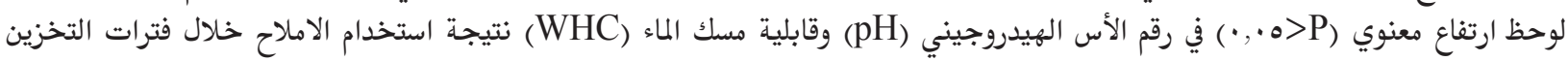

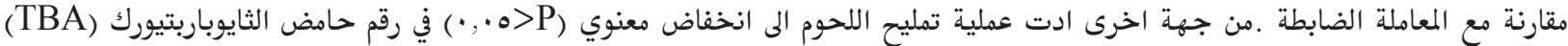

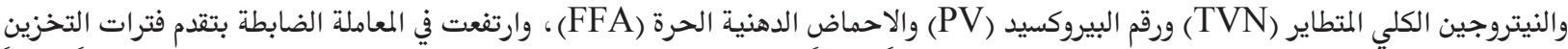

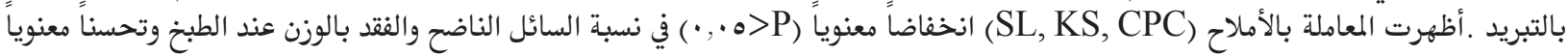

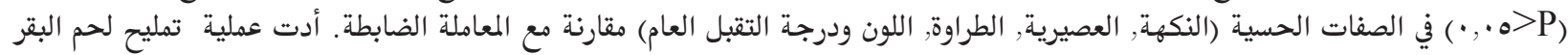

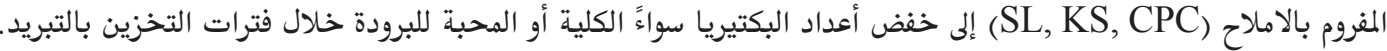

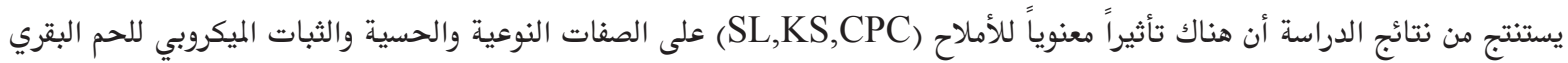
المفروم خلال فترة التخزين بالتبريد عذد عم لمدة ه ه أيام . 
